Southern Illinois University Carbondale

OpenSIUC

Publications

Department of Plant Biology

6-1994

\title{
Population Structure and Spatial Pattern in the Dioecious Shrub Ceratiola ericoides
}

David J. Gibson

Southern Illinois University at Carbondale, dgibson@plant.siu.edu

Eric S. Menges

Follow this and additional works at: http://opensiuc.lib.siu.edu/pb_pubs Published in Journal of Vegetation Science Vol. 5, No. 3 (1994): 337-346.

\section{Recommended Citation}

Gibson, David J. and Menges, Eric S. "Population Structure and Spatial Pattern in the Dioecious Shrub Ceratiola ericoides." (Jun 1994).

This Article is brought to you for free and open access by the Department of Plant Biology at OpenSIUC. It has been accepted for inclusion in

Publications by an authorized administrator of OpenSIUC. For more information, please contact opensiuc@lib.siu.edu. 


\title{
Population structure and spatial pattern in the dioecious shrub Ceratiola ericoides
}

\author{
Gibson, David J. ${ }^{*}$ \& Menges, Eric S. ${ }^{2}$ \\ ${ }^{1}$ Institute for Coastal \& Estuarine Research, University of West Florida, Pensacola, FL 32514-5751 USA; \\ ${ }^{2}$ Archbold Biological Station, P.O. Box 2057, Lake Placid, FL 33852-2057 USA; \\ *Present address: Department of Plant Biology, Southern Illinois University at Carbondale, Carbondale, \\ IL 62901-6509 USA; Tel. +1 618432 3231; Fax +1 618453 3441; E-mail GA4239@SIUCVMB.SIU.EDU
}

\begin{abstract}
The dioecious shrub Ceratiola ericoides (Florida rosemary) dominates xeric, infrequently burned Florida scrub vegetation, often to the near-exclusion of other woody species. We studied the spatial pattern, age, sex and size structure of four populations in Florida, USA: two coastal scrub populations subject to recurrent local disturbances due to sand movement, and two inland scrub populations in sites periodically burned by stand-replacing fires. The age structure of individual genets was estimated from node counts and used to describe the age structure of the populations. The sex ratio of males to females was not significantly different from $1: 1$, except within a female-biased coastal population subject to frequent sand movement. Node counts indicated that the mean age for reproductive individuals was $15-16 \mathrm{yr}$ for the inland populations and 13 - $16 \mathrm{yr}$ for the coastal populations. In all sites, there was no difference in mean age between males and females. Vegetative reproduction was uncommon except for the least-disturbed coastal population where $72 \%$ of the reproductive individuals originated through layering. Individuals were generally randomly dispersed at the coastal sites, whereas significant aggregation of males and females occurred in the inland sites where the populations were initiated following fire. Seedling recruitment was continuous in the disturbed coastal scrub site, where $35 \%$ of the individuals were juveniles. Most juveniles were dispersed from 0.5 to $0.75 \mathrm{~m}$ around females. At one of the inland sites, where juveniles comprised $11 \%$ of the population, juveniles were clustered at 0.25 to $5.75 \mathrm{~m}$ around females. Coastal populations were all-aged, while inland populations were uneven-aged. Recruitment appears to follow periods of disturbance; infrequent fire in the inland populations and continuous sand movement on the coast are factors initiating recruitment.
\end{abstract}

Keywords: Age structure; Dioecy; Florida; Layering; Recruitment; Seedling; Sex ratio; Scrub.

Nomenclature: Clewell (1985) and Wunderlin (1982).

\section{Introduction}

Since Darwin's (1877, p. 344) conclusion that dioecy evolved so that the "same individual should not have its vital powers taxed ... by producing both pollen and seed" ecologists have investigated the occurrence and distribution of male and female forms of dioecious species (Cox 1981; Bierzychudek \& Eckhart 1988). In particular, investigations have focused on the ecological relevance of sexual dimorphism (e.g. Willson 1991; Korpelainen 1992a,b) and the importance, when it occurs, of the spatial segregation of the sexes (Bierzychudek $\&$ Eckhart 1988). However, despite many studies, consistent spatial segregation of the sexes in woody species has not been found. For example, Bawa \& Opler (1977) observed that male and female plants of three dioecious tropical trees were distributed at random with respect to each other. In contrast, Grant \& Mitton (1979) reported elevational gradients in the sex ratios of Populus tremuloides. Sakai \& Oden (1983) demonstrated that in Acer saccharinum, which is polygamodioecious, this apparent incongruity was due, in part, to lack of accounting for sex and size/age interactions. Other investigations of dioecy in woody plants have incorporated population age structures for a better understanding of population dynamics; e.g. Faliński (1980a,b), Alliende \& Harper (1989), Vasiliauskas \& Aarssen (1992).

Dioecy has been investigated in several woody shrubs, e.g. Oemleria cerasiformis (Allen \& Antos 1988; Antos \& Allen 1990), Salix arctica (Dawson \& Bliss 1989), and Simmondsia chinensis (Wallace \& Rundel 1979). However, the incorporation of population age structures in studies of dioecious woody shrubs can be complicated by the difficulty in obtaining a non-destructive and accurate estimate of age. Lovett Doust \& Lovett Doust (1988), for example, had to section trunks of the dioecious shrub Rhus typhina to obtain age estimates for male and female clones. 
The evergreen dioecious woody shrub, Ceratiola ericoides (Florida rosemary; Empetraceae) is unusual in that non-destructive, accurate, age estimates can be obtained (Uphof 1931; Johnson 1982) and that genets are vulnerable to disturbances such as fire and mechanical removal of above-ground biomass. The shrub is strictly dioecious, intermediate individuals have not been observed (Gibson \& Menges unpubl.), producing large numbers of male or female flowers in the axils of the previous years leaves. The female flowers are wind pollinated (Uphof 1931). Ceratiola ericoides is often the dominant plant of coastal and inland scrub in Florida and adjacent Georgia and South Carolina (Myers 1990). Compared with other types of Florida scrub, rosemarydominated scrub occupies the most xeric, infrequently burned landscape positions (Abrahamson et al. 1984). Unlike most scrub plants, Ceratiola ericoides is killed by fire (Johnson 1982). However, dormant seed banks are present and populations recover following fire or mechanical disturbance by seedling recruitment initiating new stands (Johnson 1982; Johnson et al. 1986; Johnson \& Abrahamson 1990). It is not known how long seedling recruitment continues after fire, the extent to which populations are even- or mixed-aged, or if the numbers of male and female plants differ during stand establishment. Because Ceratiola ericoides dominates the least frequently burned part of the inland scrub landscape, its responses to fire and fire-free intervals will define the stability of this vegetation. The dynamics of Ceratiola ericoides in coastal vegetation with lowintensity disturbance is unknown.

The objective of this study was to investigate the relationship between population age structure and the spatial distribution of male, female and juvenile individuals of Ceratiola ericoides. By examining populations from contrasting parts of its range we analyze how Ceratiola ericoides populations differ under divergent disturbance regimes.

\section{Methods}

Data were collected from four $C$. ericoides populations in 1990: two coastal scrub and two inland scrub populations. Coastal scrub vegetation is affected by frequent, fine-scale disturbance from aeolian sand movement and salt spray, as well as the less frequent largescale disturbances of storms and hurricanes (Johnson \& Barbour 1990), whereas inland scrub vegetation is affected by infrequent, stand-replacing fires (Myers 1990).

\section{Study sites}

Two coastal scrub sites were selected in Escambia County, northwest Florida, one at Fort Pickens and the other at Big Lagoon State Recreation Area. Fort Pickens is a part of the Gulf Islands National Seashore located on the western end of Santa Rosa Island, a coastal barrier island $\left(30^{\circ} 18^{\prime} \mathrm{N}, 87^{\circ} 16^{\prime} \mathrm{W}\right)$. Ceratiola ericoides is a dominant shrub on established dunes on Santa Rosa Island (Burkhalter 1987), and the population studied was located in an open area to the south of the Lookout Tower north of Battery 234. Fort Pickens was a part of the Pensacola harbor fortifications from 1834 until 1947 (Muir \& Ogden 1989). Through this time period it is likely that the site was disturbed through military activities. Since 1947 the area has been a state park and from 1972 part of the Gulf Islands National Seashore. Associated species on the site included Chrysoma pauciflosculosa (bush goldenrod), Cladonia leporina (ground lichen), Helianthemum arenicola (rockrose), Polygonella polygama (October flower), and Smilax auriculata (greenbrier). Aeolian sand movement occurs on the dunes supporting Ceratiola ericoides and likely plays a role in determining vegetation composition (Burkhalter 1987). At Big Lagoon State Recreation Area $\left(30^{\circ} 18^{\prime} \mathrm{N}, 87^{\circ}\right.$ $\left.23^{\prime} \mathrm{W}\right)$, C. ericoides was sampled in a population growing on relic dunes $0.8 \mathrm{~km}$ inland from Big Lagoon the coastal lagoon behind the coastal barrier island of Perdido Key. Ceratiola ericoides occurred in sand pine scrub under an open canopy of Pinus clausa, (sand pine) with small Quercus geminata (sand-live oak) trees and $Q$. myrtifolia (myrtle oak) shrubs. There are no records of fire in the Big Lagoon study site in the last 60 years and sand movement appears less frequent than at Fort Pickens. Sand accumulation rates decrease across the width of the barrier island of Perdido Key suggesting that aeolian sand movement at Big Lagoon is minimal (Gibson unpubl.). Soils at both sites are classified as undifferentiated coastal soils (Walker \& Carlisle 1960), a type of Entisol (Brown et al. 1990).

The two inland sites were at Archbold Biological Station on the southern end of the Lake Wales Ridge in south central Florida $\left(27^{\circ} 11^{\prime} \mathrm{N} ; 81^{\circ} 21^{\prime} \mathrm{W}\right)$. Both are classified as rosemary phase of sand pine scrub (Abrahamson et al. 1984), an open shrub and herbdominated community dominated by rosemary. These support many species endemic to Florida scrub on the Lake Wales Ridge (Christman \& Judd 1990). Other associates include Quercus inopina (scrub oak), Q. geminata, and Pinus clausa. The two stands selected are on Archbold sand, a moderately well-drained white sand and are referred in this report as Archbold Bald 50 (ABS-50) and Archbold Bald 61 (ABS-61). Fire records indicate that both Archbold sites were last burned in 
1968. However, portions of each rosemary stand were not burned in this fire.

\section{Data collection}

A grid was established at each site to cover approximately $1300 \mathrm{~m}^{2}$ of rosemary-dominated scrub. Dimensions varied slightly to avoid significant oak-dominated or unvegetated areas. At Fort Pickens and Big Lagoon, the grids were $30 \mathrm{~m} \times 45 \mathrm{~m}$, whereas at Archbold the grids were $30 \mathrm{~m} \times 40 \mathrm{~m}$. Within each grid, all individual plants were mapped to $10 \mathrm{~cm}$. The minimum age of each plant was estimated by counting the maximum number of nodes on 3-10 branches. The main branches of C. ericoides produce a new whorl of branches every year. Johnson (1982) showed from ring counts that the maximum number of nodes determined from a sample of branches provides an accurate estimate of age. Since node counts underestimate ring counts, and presumably age, by 1-2 yr, 1 yr was added to our maximum node count to provide an estimate of age. Maximum height, length and width was also measured on each plant. At Big Lagoon, a large number of plants were found to be the result of layering, i.e. branches from older plants lying on the soil surface had rooted at the nodes before the parent plant died. Through soil excavation as necessary, plants were scored as layered or non-layered. All ramets of a layering individual connected by rooted branches (alive or dead) were counted as a single, layered individual. Original stem bases could not be identified with certainty. These individuals were mapped from the center of the group of connected, layered ramets. Johnson (1982) estimated that $C$. ericoides plants start layering at $35 \mathrm{yr}$ of age, we therefore estimated age by adding 35 to the age estimates. Our observations support this as a reasonable minimum estimate. For example, the oldest individual at Fort Pickens was a 33 yr old female; it was dying in the center and was just starting to layer.

\section{Data analysis}

Differences between the height of males, females, and juveniles in six age classes (1 - 4 yr, 5 - 8, 9-12, 13 $16,17-20,>20$ ) were evaluated using one-way ANOVA followed by Fisher's LSD post-hoc test to investigate differences between the means (Anon. 1992). The height data were $\log$ transformed prior to analysis. Estimates of above-ground dry weight from regression equations of Johnson et al. (1986) were similarly analyzed; however, significant differences between sexes and age classes were the same as for height and so these data and results are not presented here.

The spatial distribution of male, female, and juvenile plants was assessed by calculating the coefficient of aggregation (CA) for each according to Hopkins (1954). Significance was tested according to Greig-Smith (1983). Goodall \& West (1979) showed that Hopkins' CA is a powerful index for assessing departure from random distributions of individuals censused using distance measures. Since CA is dependent upon random samples, the mean of 20 iterations was used as suggested by Briggs \& Gibson (1992).

To test for differences in the dispersion of juveniles around potential parent female plants, the procedure developed by Hammill \& Wright (1986) was used. This procedure tests the null hypothesis that one set of points (the juveniles) is located at random with respect to another set of points (the females) in the mapped area. The measure of dispersion is the observed cumulative distribution of distances from one set of points to the other. Deviation from the cumulative distribution according to the null hypothesis is tested using the Kolmogorov-Smirnov (KS) test. Hammill \& Wright (1986) describe the procedure in detail, and examples of its application can be found in Hubbell \& Foster (1987), Wright \& Howe (1987) and Briggs \& Gibson (1992).

\section{Results}

Of all plants, about $43.3 \%$ were female, $40.2 \%$ male, and $16.5 \%$ juvenile (non-flowering). Sex ratios did not differ from the null hypothesis of a 1:1 ratio at 3 of 4 sites and for both layering and non-layering portions of the Big Lagoon population. At Fort Pickens, there was a significant excess of females over males (59\%: $41 \%$; Table 1).

The numbers of juveniles varied widely among populations (Table 1). The Fort Pickens population had a relatively high proportion of juveniles $(35 \%$ of all plants) compared to the other three populations $(<12 \%)$. Fort Pickens also had the highest ratio of juveniles to

Table 1. Numbers of Florida Ceratiola ericoides at four sites in Florida. The $\chi^{2}$ statistic compares the number of male and female plants and is calculated based on an expected 1:1 ratio of males to females; ${ }^{* *}=P<0.01$, for all others $P>0.05$.

\begin{tabular}{lcrccc}
\hline Site & Total & Male & Female & $\chi^{2}$ & Juveniles \\
\hline Fort Pickens & 642 & 172 & 243 & $12.15^{* *}$ & 227 \\
Big Lagoon & & & & & \\
All plants & 408 & 192 & 195 & 0.02 & 21 \\
Layering & 282 & 132 & 145 & 0.61 & 5 \\
Non-layering & 126 & 60 & 50 & 0.91 & 16 \\
ABS-50 & 321 & 166 & 146 & 1.28 & 9 \\
ABS-61 & 537 & 217 & 257 & 3.37 & 63 \\
& & & & & \\
Total & 1908 & 747 & 841 & 2.22 & 320 \\
\hline
\end{tabular}



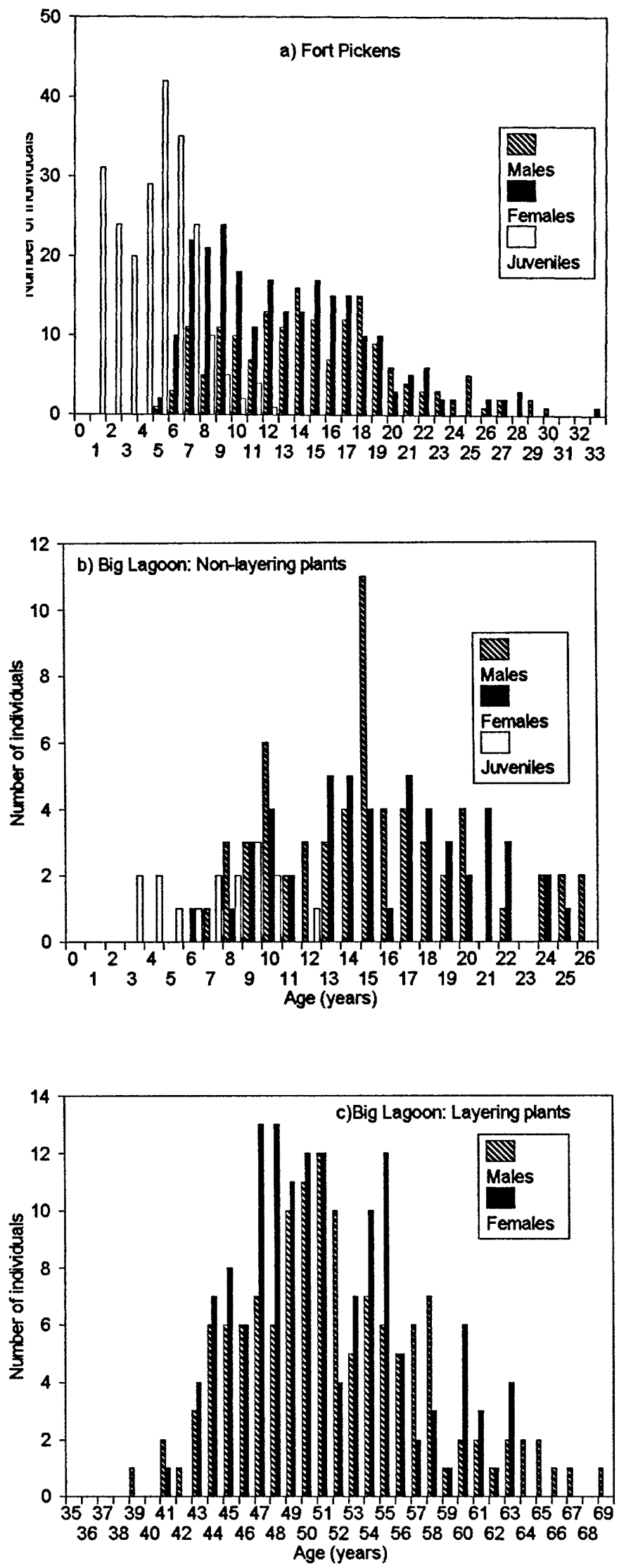

Fig. 1. Numbers of male, female, and juvenile Ceratiola ericoides individuals of different ages at four sites; (a) Fort Pickens, (b) Big Lagoon State Park layering plants, (c) Big Lagoon State Park non-layering plants;

overleaf: (d) Archbold Bald 50, and (e) Archbold Bald 61. 


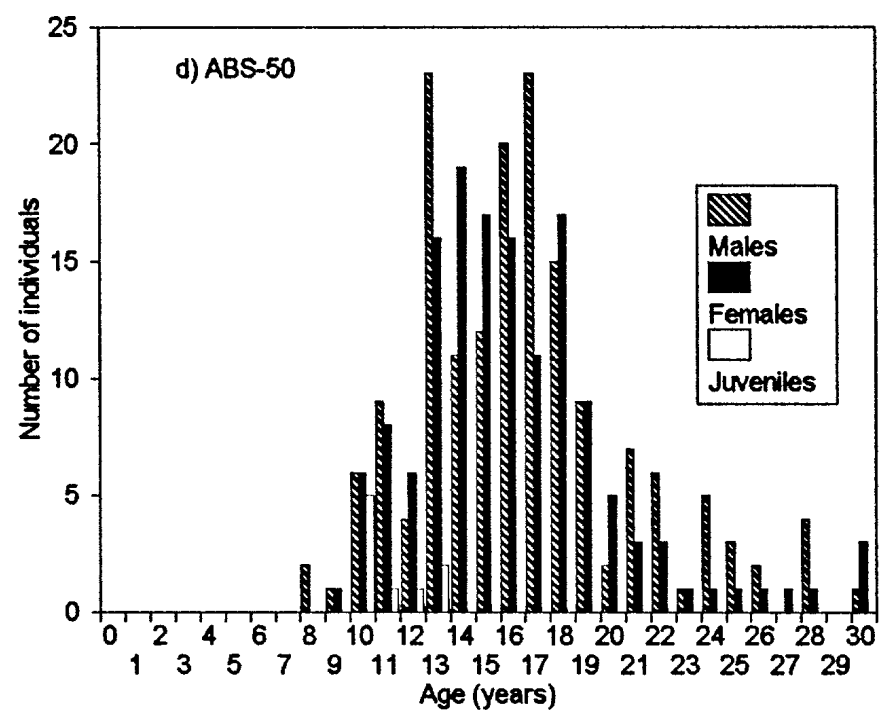

Fig. 1. Cont.

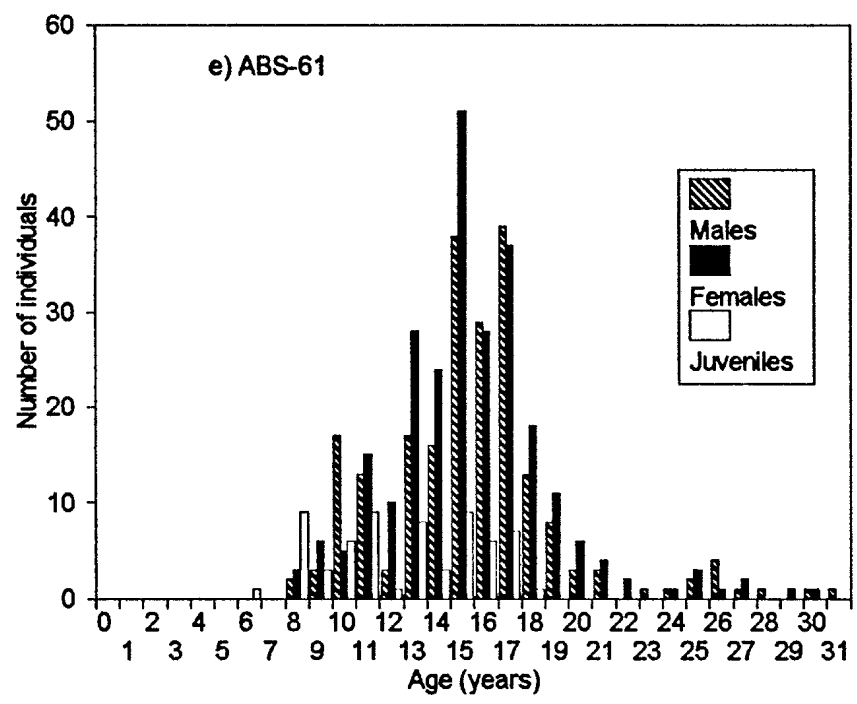

females $(0.93)$ compared with the other three populations $(0.25,0.11,0.06)$. Densities of juvenile plants increased

Table 2. Coefficient of Aggregation (CA) of male, female, and juvenile Ceratiola ericoides plants from four sites.

\begin{tabular}{|c|c|c|c|c|}
\hline Site & Male & Female & Juvenile & All plants \\
\hline Fort Pickens & $0.71^{*}$ & 1.19 & $3.05^{* * *}$ & 1.33 \\
\hline \multicolumn{5}{|l|}{ Big Lagoon } \\
\hline Layering & 1.09 & 1.14 & 1.82 & 1.14 \\
\hline Non-layering & $1.49^{*}$ & 0.93 & 0.94 & 1.07 \\
\hline All plants & 1.14 & 1.05 & 1.05 & 1.15 \\
\hline ABS-50 & $1.66^{* * * *}$ & $2.24^{* * *}$ & $13.19^{* * *}$ & $1.96^{* * * *}$ \\
\hline ABS-61 & $2.82^{* * *}$ & $3.64^{* * *}$ & $12.25^{* * *}$ & $3.63^{\text {*** }}$ \\
\hline
\end{tabular}

exponentially with female-biased sex ratios across the four populations (Pearson correlation $=0.95, P=0.05$ ).

Age distributions varied among populations. The two coastal populations had all-aged distributions, but the distributions differed in shape. Fort Pickens plants ranged up to $33 \mathrm{yr}$ of age, but few plants were older than $20 \mathrm{yr}$. Juveniles under $8 \mathrm{yr}$ of age were abundant (Fig. 1). As the numbers of juveniles decreased from $5-12 \mathrm{yr}$ of age, the numbers of 5-12 yr-old males and females increased. Additionally, there were significantly more females than males between $8-11 \mathrm{yr}$ of age $\left(\chi^{2}=8.8, P\right.$ $<0.005)$. At Fort Pickens, the numbers of males and females in the population peaked between 12 and $18 \mathrm{yr}$.

Plants at Big Lagoon were estimated to reach up to $69 \mathrm{yr}$ of age (Fig. 1 b,c), with few plants under 8 yr of age. If layered plants are at least $35 \mathrm{yr}$ of age, then the layered plants may have been primarily 40-60 yr old, compared to the non-layered plants which ranged from 

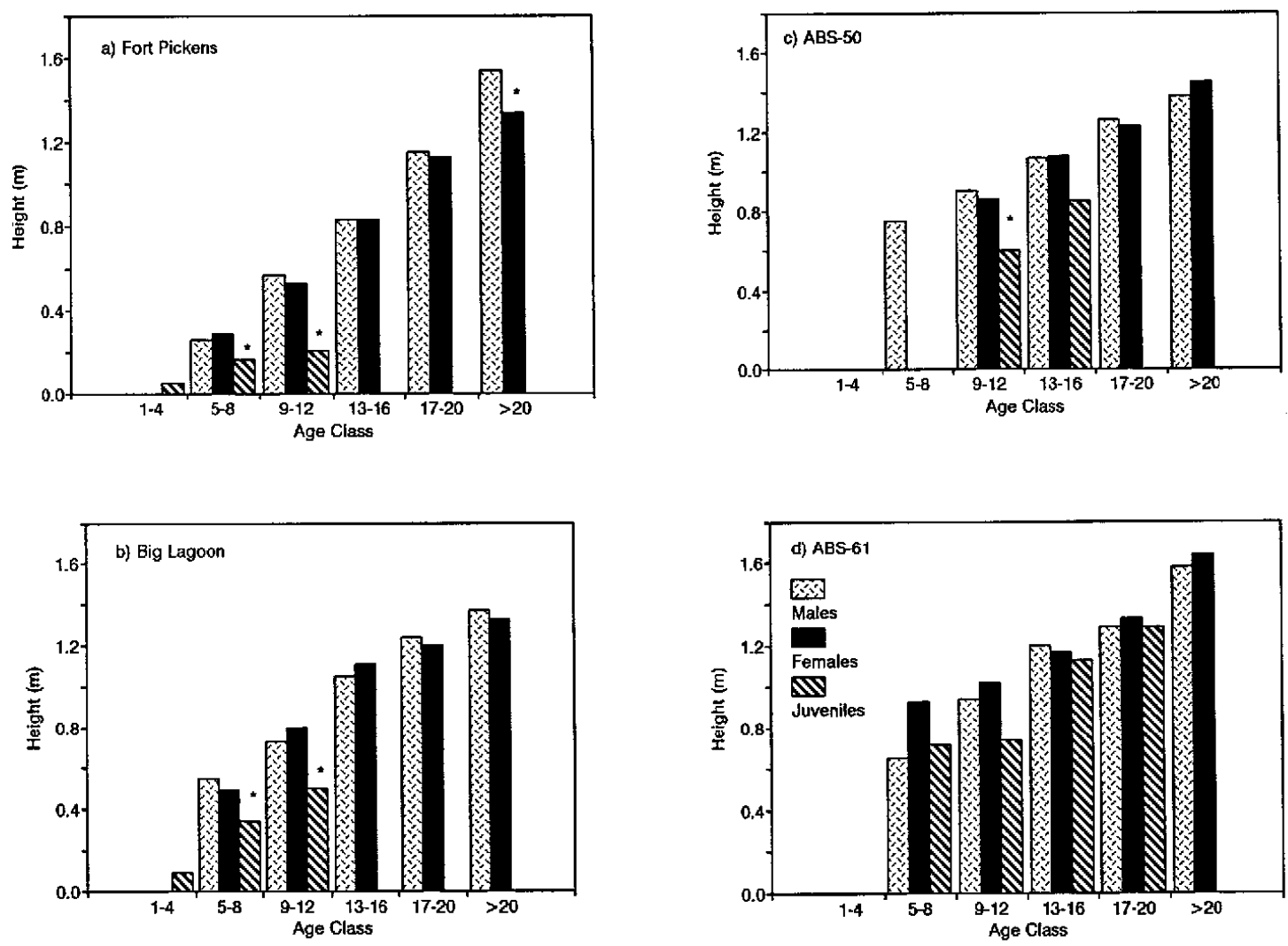

Fig. 2. Height of male, female, and juvenile Ceratiola ericoides individuals in six age classes at four sites; (a) Fort Pickens, (b) Big Lagoon, (c) Archbold Bald 50, and (d) Archbold Bald 61. Asterisks (*) indicate significant differences between males and females (Fort Pickens > 20-yr-old plants), and between juveniles and both males and females (Fort Pickens, Big Lagoon, ABS-50) (Fisher's LSD). Legend for all is shown in (d).

3-27 yr of age. With the exception of eleven $15 \mathrm{yr}$ old males, there was no distinct peak of individuals of any single age.

In contrast to the all-aged coastal populations, inland populations were uneven-aged, and dominated by a single cohort. At Archbold Bald 50, most plants were 13-19 yr of age, but a few ranged to $30 \mathrm{yr}$ (Fig. 1d). Plants under $10 \mathrm{yr}$ old were virtually absent. Archbold Bald 61 was also dominated by 13-19yr-old plants, with only a few older (to $31 \mathrm{yr}$ ) or younger (Fig. 1e). In both populations there were no juveniles less than $8 \mathrm{yr}$ of age.

Male, female and juvenile plants showed a consistent increase in height with age (Fig. 2). The largest juveniles occurred in the Archbold Bald 61 population; these juveniles were also the oldest. Except for 13-16 yr old plants at Archbold Bald 50 and all individuals at Archbold Bald 61, juveniles were significantly shorter than males and females in the same age class. With the exception of the larger males in the oldest age class at Fort Pickens, male and female plants were not significantly different in height (Fig. 2).
Plants were aggregated at both inland sites, as were population subsets (males, females, juveniles) (Table 2). Aggregation was most pronounced for juveniles and less so for reproducing plants. At Fort Pickens, the same patterns were evident, but the degree of aggregation was less pronounced than at the Archbold site. At Big Lagoon (Table 2), however, plants did not show a departure from a random distribution.

Juveniles tended to be aggregated around female plants at Fort Pickens (Fig. 3a). Significant contagious distributions, relative to a null model, occurred within 0.5-0.75 m. At Archbold Bald 61, significant association was found at all distances less than $5.75 \mathrm{~m}$ (Fig. 3b). The observed cumulative probabilities reach the upper limit of 1.0 within $1 \mathrm{~m}$ reflecting strong and contagious aggregation of juveniles around females. Recruitment at other sites was not sufficient to test for juvenile-female associations. 

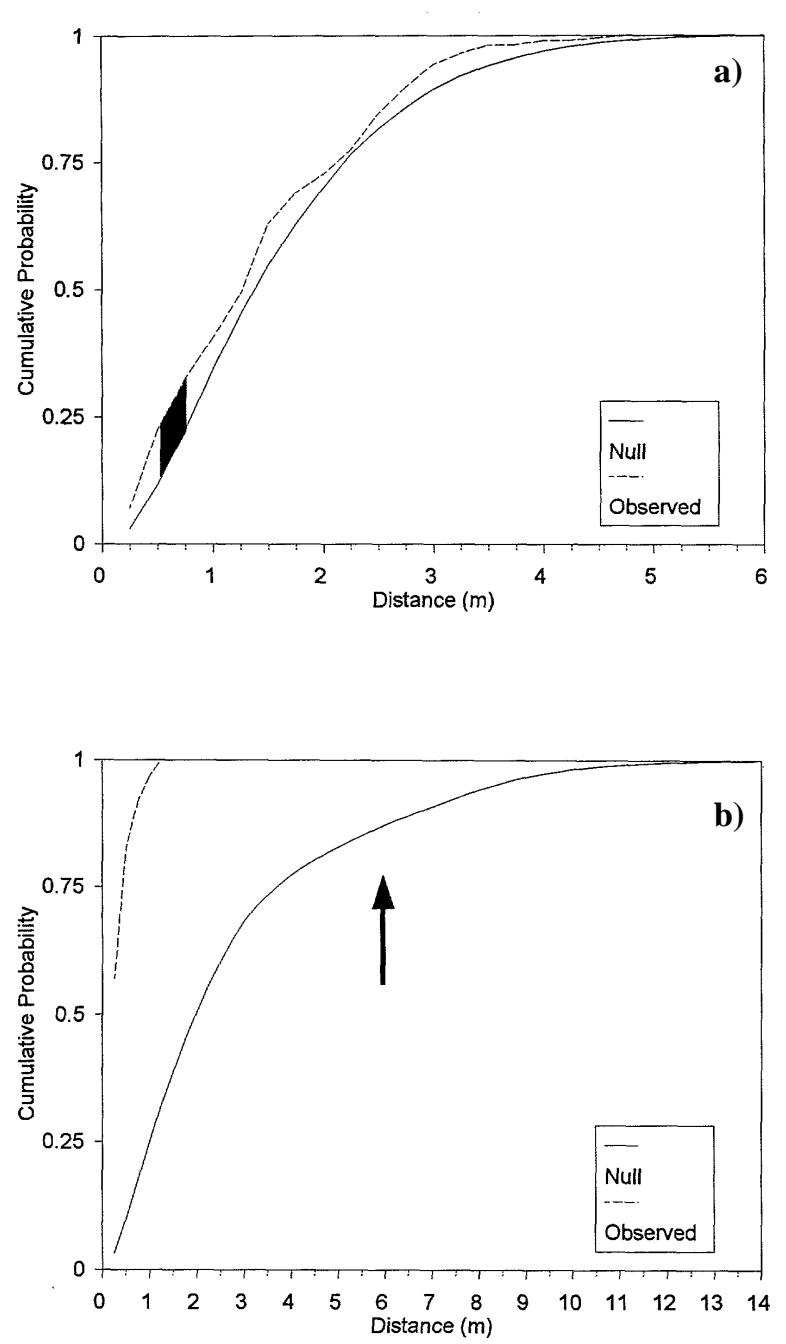

Fig. 3. Dispersion of juveniles around females of Ceratiola ericoides at (a) Fort Pickens (shaded area indicates a significant departure of the observed distribution from the null model (Kolmogorov-Smirnov test)) and (b) Archbold Bald 61 (significant departure of the observed distribution from the null model (Kolmogorov-Smirnov test) occurs at all distances less than $5.75 \mathrm{~m}$ (arrowed)).

\section{Discussion}

Sex ratios were not different from 1:1 in 3 of the 4 stands of Ceratiola ericoides (Table 1). This is in agreement with Fisher (1930) who pointed out that under the influence of natural selection and in the absence of modifying environmental factors sex ratios should be 1:1 if there is an equal cost to the parents of male and female offspring (Allen \& Antos 1993). Several subsequent field studies of dioecy have observed this sex ratio (e.g. Opler \& Bawa 1978; Vasiliauskas \& Aarssen 1992). In the coastal site where the ratio was not 1:1 (Fort
Pickens), 8 - 11 yr old females were more abundant than males. In three other nearby populations of $C$. ericoides at Fort Pickens, females also outnumbered males (Gibson unpubl.). It is not clear why a female-biased sex ratio should occur within a population of $C$. ericoides, although recruitment related to disturbance may be important. The Fort Pickens site was the most frequently disturbed of the four sites as it is within $0.5 \mathrm{~km}$ of the coast and subject to wind-blown sands, as well as trampling from human visitors passing through the site to the adjacent beach. Coupled with the high density of individuals, this population is and has been actively reproducing and recruiting for several years.

Willson \& Burley (1983) pointed out that deviations from Fisher's predictions are expected to result from environmental constraints on one sex over the other. Female-biased sex ratios in wind-pollinated plants, such as Ceratiola ericoides, may optimise seed production (Kaplan 1972). The optimum sex ratio for populations at high densities, such as at the Fort Pickens site, should be $<0.5$; and at Fort Pickens the sex ratio (number of males/ total males + females, calculated from data in Table 1) was 0.41 , in accord with the expectations of Kaplan's (1972) model. At the other sites where the density was lower, the sex ratio ranged 0.46 - 0.54 ; also in support of Kaplan's (1972) model for lower density populations. Lloyd (1974) and Alliende \& Harper (1989) however, argue that this is a group-selectionist approach since selection operates at the level of the individual and not the population. The ecological importance of the differing ratios of males to females is suggested by the observation that the density of juveniles increased as percentages of females at a site became larger. This provides some evidence for differential initiation of flowering.

The $8-11$ yr old age class, in which the female bias occurred, corresponds to the onset of sexual reproduction in $C$. ericoides. The sex of individuals that were not flowering (i.e. juveniles) was unknown and so the true genet-based sex ratio is unknown (Allen \& Antos 1993). As suggested by Smith (1963) for Rumex hastatulus, it is possible that more females than males occur at the time of germination and seedling establishment. This would violate Fisher's prediction directly and would imply apomixis or certation. In C. ericoides, this bias would not be revealed in juveniles, but could later be manifested when plants reach sexual maturity at $8-11$ yr. The loss of the female bias in older age classes, bringing the population back to the expected Fisherian 1:1 ratio, implies differential mortality of females as they enter the reproductive age classes; i.e. an ecological explanation related perhaps to the physiological stress associated with the onset of reproduction. Crawford \& Balfour (1983) implicated physiological stress 
affecting sex ratios in arctic willows. Korpelainen (1992b) showed that female-biased sex ratios in the sexually dimorphic Rumex acetosa and $R$. acetosella were due to a physiological advantage conferred upon taller females. For $C$. ericoides, the proximate cause of such a physiological stress disproportionally affecting females that is apparently only manifest at the most disturbed coastal site is unknown. As in other species (Allen \& Antos 1993), it is perhaps more likely that female plants reach sexual maturity at a younger age than male plants, and thus be identifiable as females earlier. Purrington (1993) showed that this can result under low nutrient conditions.

Related to the general similarity in sex ratios, the age structure and height of males and females was not different within any of the four populations, including the coastal Fort Pickens site where the female bias in numbers occurred (Table 1, Figs. 1,2). Neither did biomass estimates based upon height and measurements of yearly growth rate from branch internode lengths reveal any differences between the sexes within or between age classes (Gibson unpubl.). Several previous studies of dioecious woody species have shown females to display less vegetative growth than males (e.g. Herrera 1988; Vasiliauskas \& Aarssen 1992), although Alliende \& Harper (1989) found no difference in the size of males and females even within a female biased population. Unlike Alliende \& Harper's (1989) findings for Salix cinerea, juveniles of $C$. ericoides were not of the same size as adults within an age class except in one of the inland populations (ABS-61, Fig. 2).

Patterns of age distribution varied between the four sites. At both inland sites, most recruitment occurred within a decade of a fire in 1968 (Fig. 1d, e). This pattern concurs with Johnson's (1982) and Johnson et al.'s (1986) observations that this species reestablishes after stand-destroying fires through seed germination rather than vegetative sprouting from surviving resprouts; i.e. a post-fire 'seeder' as opposed to a 'sprouter' (sensu Keeley \& Zedler 1978). At Archbold, the period of post-fire recruitment extended nearly one decade with sporadic recruitment later on. Our findings suggest that even-aged stands of Ceratiola ericoides should not be expected due to several years of post-fire recruitment, sporadic recruitment between fires, and the tendency of fire not to burn completely through the sparse rosemarydominated scrub. Such a strategy allows $C$. ericoides to become the dominant plant in post-fire inland scrub competing strongly against other plants (e.g. Kilian \& Cowling 1992).

At the coastal sites the patterns of recruitment were different from those of the inland sites. At Fort Pickens, the population was all-aged with evidence of continuous, although variable, recruitment for at least $20 \mathrm{yr}$
(Fig. 1a). Johnson (1986) has indicated that scarification is necessary for $C$. ericoides seed germination, and it is likely that frequent disturbance from windblown sand allows seeds to germinate and provides open sites for establishment resulting in continuous recruitment (e.g. van der Valk 1974). Gibson \& Looney (1994) indicate that aeolian sand movement was one of several environmental factors related to vegetation composition on a nearby coastal barrier island. The other coastal site, Big Lagoon, illustrates the effects of fire exclusion and reduced sand movement upon rosemary populations (Fig. 1b, c). Two distinct cohorts of individuals exist at this site. A cohort of individuals estimated to be 40-60 yr old likely represent the population of individuals colonizing the site following the last fire. These individuals all exhibited layering, a feature of $C$. ericoides after $35 \mathrm{yr}$ of age (Johnson 1982). Vegetative reproduction through layering is allowing this species to persist in the absence of extensive seedling initiating disturbances such as fire and major sand movement. Keeley (1992) showed that Adenostoma fasciculatum in California chaparral showed a similar demographic pattern of high levels of seeding recruitment following fire coupled with basal sprouting in unburned sites. A second much smaller cohort was 3-27 yr old, likely representing sporadic recruitment perhaps following sand movement.

Juveniles were dispersed at short distances around females (Fig. 3) in the two sites with sufficient recruitment for analysis. This pattern corresponds to model 3 of Hammill \& Wright (1986) suggesting limited dispersion of fruit around parents. Nonetheless, Johnson (1982) reports that rosemary fruits are eaten by harvester ants (Pogonomyrex badius) and mice (Peromyscus polionotus), and seeds from ingested fruit pass intact through the digestive system of the rufous-sided towee (Pipilo erythropthalamus) and the scrub jay (Aphelocoma coerulescens). Bird dispersal offers the potential for long-distance dispersal (Briggs \& Gibson 1992), but it apparently does not obscure the clumped distribution observed in this study. Female $C$. ericoides produce abundant fruits late in the year (Uphof 1931), and a persistent seed bank is present (Menges unpubl.). Recruitment may occur after disturbances from a seed bank representing many seasons of seed production and the vagaries of dispersal by different organisms. Heavy seed predation by ants may also affect seed densities and subsequent recruitment patterns. An alternative explanation is that there is a random distribution of fruits with respect to female parents, but establishment of seedlings is limited to the immediate proximity of females. Thus, as suggested by Houle (1992), good seed dispersal coupled with germination and seedling establishment microsites that are highly specific would also explain 
these observations. Data on the fruit and seed rain pattern would be necessary to investigate this scenario.

Significant aggregation of males and females as well as juveniles at the inland sites suggests that an aggregated pattern of seed dispersal best accounts for the dispersal pattern of juveniles. As in Wright \& Howes' (1987) study of desert shrubs, the juveniles were more strongly aggregated than the adults, indicating a trend towards random distributions during the course of juvenile mortality and self-thinning. In contrast, Briggs \& Gibson (1992) reported an increase in the magnitude of aggregation with an increase in tree height (and presumably age) of three tree species invading tallgrass prairie suggesting that these species became more aggregated as the trees aged. The patterns of aggregation for $C$. ericoides in this study were not observed at the Big Lagoon site where the number of juveniles was low.

\section{Conclusions}

This study has demonstrated some general patterns of population structure in a dioecious shrub in four contrasting populations across its range. Recruitment appears episodic following disturbance, either fire at inland sites or sand movement on the coast, but continues for nearly a decade following fire. Under conditions of frequent disturbance, as in the coastal environment, near continuous recruitment occurs with a female-biased population structure for individuals at the onset of reproduction. Low rates of sand movement and, in particular, episodic fire events, cause recruitment and thus age structure to be more uneven through time. The differences in recruitment indicate that, for this dioecious species, demographic parameters of populations are structured according to the local disturbance regime.

Acknowledgements. Bruce Boler, Christy Draper, Noreen Gallo, Nancy Kohfeldt, Elaine Luna-Martin, and Bill Mundell provided field assistance. Beth Middleton, Dan Nickrent and two anonymous reviewers provided critical reviews of a draft of the manuscript. Partial financial support to DJG was provided by the University of West Florida Committee on Research and Creative Activities and the United States Department of Interior through the National Park Service (Cooperative Agreement Number CA-5320-9-8001). Access to the Big Lagoon field site was granted by the Florida Department of Natural Resources, and to Fort Pickens by the National Park Service. This is ICER Publication Number PUB94-1.

\section{References}

Anon. 1992. SAS version 6.06. SAS Institute, Inc. Cory, NC.

Abrahamson, W.G., Johnson, A.F., Layne, J.N. \& Peroni, P.A. 1984. Vegetation of the Archbold Biological Station, Florida: An example of the southern Lake Wales Ridge. Fla. Sci. 47: 209-250.

Allen, G.A. \& Antos, J.A. 1988. Relative reproductive effort in males and females of the dioecious shrub Oemleria cerasiformis. Oecologia (Berl.) 76: 111-118.

Allen, G.A. \& Antos, J.A. 1993. Sex ratio variation in the dioecious shrub Oemleria cerasiformis. Am. Nat. 141: 537-553.

Alliende, M.C. \& Harper, J.L. 1989. Demographic studies of a dioecious tree. I. Colonization, sex and age structure of a population of Salix cinerea. J. Ecol. 77: 1029-1047.

Antos, J.A. \& Allen, G.A. 1990. A comparison of reproductive effort in the dioecious shrub Oemleria cerasiformis using N, energy and biomass and currencies. Am. Midl. Nat. 124: 254-262.

Bawa, K.S. \& Opler, P.A. 1977. Spatial relationships between staminate and pistillate plants of dioecious tropical forest trees. Evolution 31: 64-68.

Bierzychudek, P. \& Eckhart, V. 1988. Spatial segregation of the sexes of dioecious plants. Am. Nat. 132: 43-43.

Briggs, J.M. \& Gibson, D.J. 1992. Effect of fire on tree spatial patterns in a tallgrass prairie landscape. Bull. Torrey Bot. Club 119: 300-307.

Brown, R.B., Stone, E.L. \& Carlisle, V.W. 1990. Soils. In: Myers, R.L. \& Ewel, J.J. (eds.) Ecosystems of Florida, pp. 35-69. University of Central Florida Press, Orlando, FL.

Burkhalter, J.R. 1987. An ecological study of coastal strand vegetation on the western end of Santa Rosa Island near Pensacola, Florida. M.Sc. thesis, University of West Florida, Pensacola, FL.

Christman, S.P. \& Judd, W.J. 1990. Notes on plants endemic to Florida scrub. Fla Sci. 53: 52-73.

Clewell, A.F. 1985. Guide to the vascular plants of the Florida panhandle. Univ. Presses of Florida, Talahassee, FL.

Cox, P.A. 1981. Niche partitioning between sexes of dioecious plants. Am. Nat. 117: 295-307.

Crawford, R.M.M. \& Balfour, J. 1983. Female predominant sex ratios and physiological differentiation in arctic willows. J. Ecol. 71: 149-160.

Darwin, C.R. 1877. Different forms of flowers on plants of the same species. D. Appleton, New York, NY.

Dawson, T.E. \& Bliss, L.C. 1989. Patterns of water use and tissue water relations in the dioecious shrub, Salix arctica: The physiological basis for habitat partitioning between the sexes. Oecologia (Berl.) 79: 332-343.

Faliński, J.B. 1980a. Vegetation dynamics and sex structure of the populations of pioneer dioecious woody plants. Vegetatio 43: 23-38.

Faliński, J.B. 1980b. Changes in the sex- and age-ratio in populations of pioneer dioecious woody species (Juniperus, Populus, Salix) in connection with the course of vegetation succession in abandoned farmlands. Ekol. Pol. 28: 327-365.

Fisher, R.A. 1930. The genetical theory of natural selection. 
Clarendon Press, Oxford.

Gibson, D.J. \& Looney, P.B. 1994. Vegetation colonization of dredge spoil on Perdido Key, Florida. J. Coastal Res. 10: 133-143.

Goodall, D.W. \& West, N.E. 1979. A comparison of techniques for assessing dispersion patterns. Vegetatio 40: 1527.

Grant, J. \& Mitton, J.B. 1979. Elevational gradients in adult sex ratios and sexual differentiation in vegetative growth rates of Populus tremuloides Michx. Evolution 33: 914918.

Greig-Smith, P. 1983. Quantitative plant ecology, 3rd ed. Blackwell Scientific Publications, Oxford.

Hammill, D.N. \& Wright, S.J. 1986. Testing the dispersion of juveniles relative to adults: A new analytic method. Ecology 67: 952-957.

Herrera, C.M. 1988. Plant size, spacing patterns, and hostplant selection in Osyris quadripartita, a hemiparasitic dioecious shrub. J. Ecol. 76: 995-1006.

Hopkins, B. 1954. A new method for determining the type of distribution of plant individuals. Ann. Bot. London 18: 213-227.

Houle, G. 1992. Spatial relationship between seed and seedling abundance and mortality in a deciduous forest of northeastern North America. J. Ecol. 80: 99-108.

Hubbell, S.B. \& Foster, R.B. 1987. The spatial context of regeneration in a neotropical forest. In: Gray, A.J., Crawley, M.J. \& Edwards, P.J. (eds.) Colonization, succession and stability, pp. 395-442. Blackwell Sci. Publ., Oxford.

Johnson, A.F. 1982. Some demographic characteristics of the Florida Rosemary Ceratiola ericoides Michx. Am. Midl. Nat. 108:170-174.

Johnson, A.F. 1986. Recipe for growing Florida rosemary: Main ingredient: Patience! Palmetto, Spring, 1986: 5.

Johnson, A.F. \& Abrahamson, W.G. 1990. A note on the fire responses of species in rosemary scrubs on the southern Lake Wales Ridge. Fla. Sci. 53:138-144.

Johnson, A.F. \& Barbour, M.G. 1990. Dunes and maritime forests. In: Myers, R.L. \& Ewel, J.J. (eds.) Ecosystems of Florida, pp. 429-480. University of Central Florida Press, Orlando, FL.

Johnson, A.F., Abrahamson, W.G. \& McCrea, K.D. 1986. Comparison of biomass recovery after fire of a seeder (Ceratiola ericoides) and a sprouter (Quercus inopina) species from South-central Florida. Am. Midl. Nat. 116: 423-428.

Kaplan, S.M. 1972. Seed production and sex ratio in anemophilous plants. Heredity 28: 281-285.

Keeley, J.E. 1992. Demographic structure of California chaparral in the long-term absence of fire. J. Veg. Sci. 3: 79-90.

Keeley, J.E. \& Zedler, P.H. 1978. Reproduction in chaparral shrubs after fire: a comparison of sprouting and seeding strategies. Am. Midl. Nat. 99: 142-162.

Kilian, D. \& Cowling, R.M. 1992. Comparative seed biology and co-existence of two fynbos shrub species. J. Veg. Sci. 3: 637-646.

Korpelainen, H. 1992a. Patterns of resource allocation in male and female plants of Rumex acetosa and $R$. acetosella.
Oecologia (Berl.) 89: 133-139.

Korpelainen, H. 1992b. Patterns of phenotypic variation and sexual size dimorphism in Rumex acetosa and $R$. acetosella. Bot. Helv. 102: 109-120.

Lloyd, D.G. 1974. Female-predominant sex ratios in angiosperms. Heredity 32: 35-44.

Lovett Doust, J. \& Lovett Doust, L. 1988. Modules of production and reproduction in a dioecious clonal shrub, Rhus typhina. Ecology 69: 741-750.

Muir, T. \& Ogden, D.P. 1989. The Fort Pickens Story. Pensacola Historical Society, Pensacola, FL.

Myers, R.L. 1990. Scrub and high pine. In: Myers, R.L. \& Ewel, J.J. (eds.) Ecosystems of Florida, pp. 150-193. University of Central Florida Press, Orlando, FL.

Opler, P.A. \& Bawa, K.S. 1978. Sex ratios in tropical forest trees. Evolution 32: 812-821.

Purrington, C. 1993. Parental effects on progeny sex ratio, emergence, and flowering in Silene latifolia (Caryophylaceae). J. Ecol. 81: 807-812.

Sakai, A.K. \& Oden, N.L. 1983. Spatial pattern of sex expression in silver maple (Acer saccharinum L.): Morista's index and spatial autocorrelation. Am. Nat. 122: 489-508.

Smith, B.W. 1963. The mechanism of sex determination in Rumex hastatulus. Genetics 48: 1265-1288.

Uphof, J.C.T. 1931. Quelques contributions à la connaissance de la famille des Empétracées (Ceratiola ericoides Michx). Bull. Soc. Bot. France 78: 26-34.

van der Valk, A.G. 1974. Environmental factors controlling the distribution of forbs on coastal foredunes in Cape Hatteras National Seashore. Can. J. Bot. 52: 1057-1073.

Vasiliauskas, S.A. \& Aarssen, L.W. 1992. Sex ratio and neighbor effects in monospecific stands of Juniperus virginiana. Ecology 73: 622-632.

Walker, J.H. \& Carlisle, V.W. 1960. Soil Survey of Escambia County, Florida. United States Department of Agriculture, Washington D.C.

Wallace, C.S. \& Rundel, P.W. 1979. Sexual dimorphism and resource allocation in male and female shrubs of Simmondsia chinensis. Oecologia (Berl.) 44: 34-39.

Willson, M. F. 1991. Sexual selection, sexual dimorphism and plant phylogeny. Evol. Ecol. 5: 69-87.

Willson, M.F. \& Burley, N. 1983. Mate choice in plants: tactics, mechanisms, and consequences. Princeton Univ. Press, Princeton, NJ.

Wright, S.J. \& Howe, H.F. 1987. Pattern and mortality in Colorado desert plants. Oecologia (Berl.) 73: 543-552.

Wunderlin, R.P. 1982. Guide to the vascular plants of central Florida. Univ. Presses of Florida, Tampa, FL.

Received 6 July 1993; Revision received 22 February 1994; Accepted 3 March 1994. 